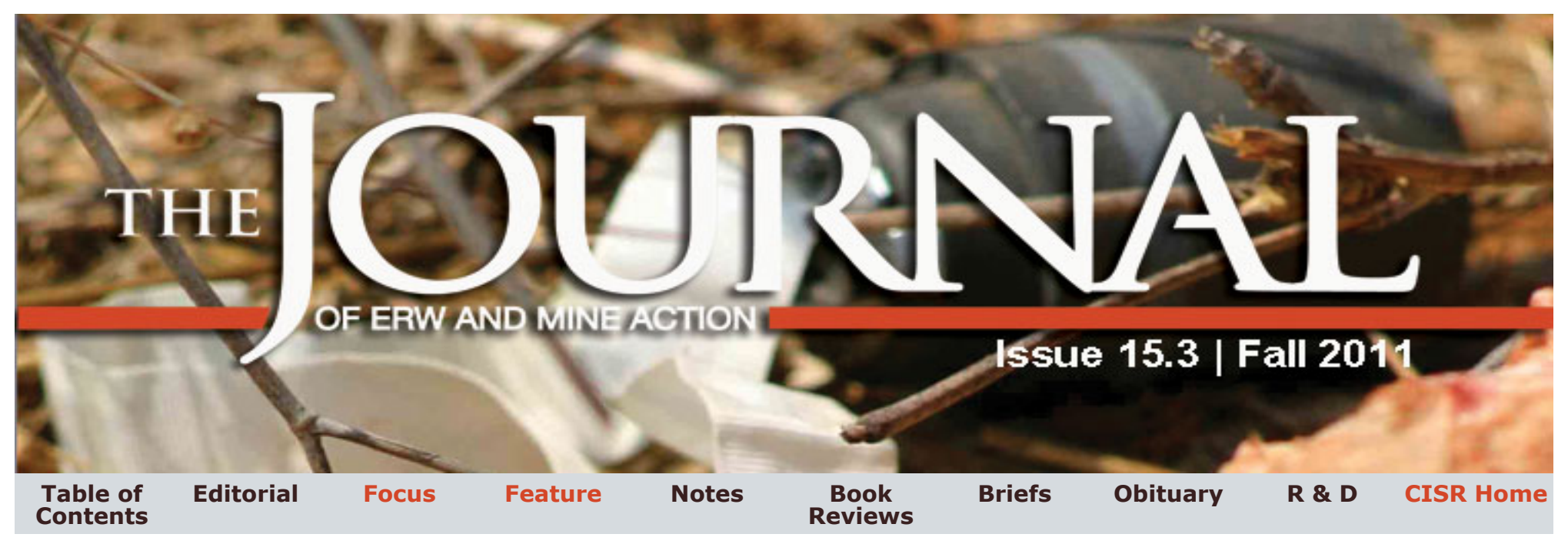

\title{
Crescent and Dove: Peace and Conflict Resolution in Islam
}

\author{
Edited by Qamar-ul Huda \\ United States Institute of Peace Press, 2010 \\ ISBN: 978-1-60127-060-3 \\ Cost: US\$16.00
}

Crescent and Dove: Peace and Conflict Resolution in Islam_is a collection of essays synthesized by Qamar-ul Huda to create a compelling read for peacemakers, mine-action experts and anyone interested in conflict studies. The authors elaborate on Islamic approaches to nonviolence while bridging the gaps between economic thought, political science, religious texts and spirituality.

The American media's negative portrayals of Islam tend to overshadow Islamic peace movements and activism. Crescent and Dove offers a strong antidote to this representation, through essays like Zeki Saritoprak's inspiring "Bediüzzaman Said Nursi's Paradigm of Islamic Non-Violence." The subject of Saritoprak's essay, Nursi, was born in Turkey and was as influential a figure to his country as Mahatma Gandhi was to India. Nursi was not only a university professor, but he was also commander of a military unit during World War I. He led a life dedicated to the Islamic doctrine of nonviolence, which he supplemented with teachings from the Quran. His devotion to nonviolence is comparable to the leaders of the American Civil Rights Movement.

To better gain an understanding of peacebuilding activities in Muslim countries, Waleed El-Ansary's "Revisiting the Qur'anic Basis for the Use of War Language" is a must-read. Grounding important linguistic considerations in religious text as well as modern societal context, El-Ansary elucidates the proper usage and history of words such as mujahideen and jihad. These words and their usage in peacebuilding operations cannot be misunderstood or underestimated, and El-Ansary offers clear and operative meanings of these and other words of importance.

Finally, the essay by Asna Husin, "Islamic Peace Education," offers an example of a peacebuilding movement in Islamic society. The author highlights a peace education program in Aceh, a region of Sumatra, Indonesia. The Program Pendidikan Damai was founded in 2000 in the face of violence and bloodshed in Aceh. Administrators from various high schools crafted a peace curriculum, which was eventually implemented in schools across Aceh.

Crescent and Dove: Peace and Conflict Resolution in Islam is a milestone that paves the way for more volumes of its kind. By representing Islam and its various societal implications in a balanced and positive light, the book shines as a beacon of knowledge that will no doubt find its way into libraries, college classrooms and the shelves of anyone with a passion for peace or peace studies. I

\section{Reviewed by Shivani Bhatt, CISR Staff.}

Center for International Stabilization and Recovery

James Madison University

Harrisonburg, VA / USA 


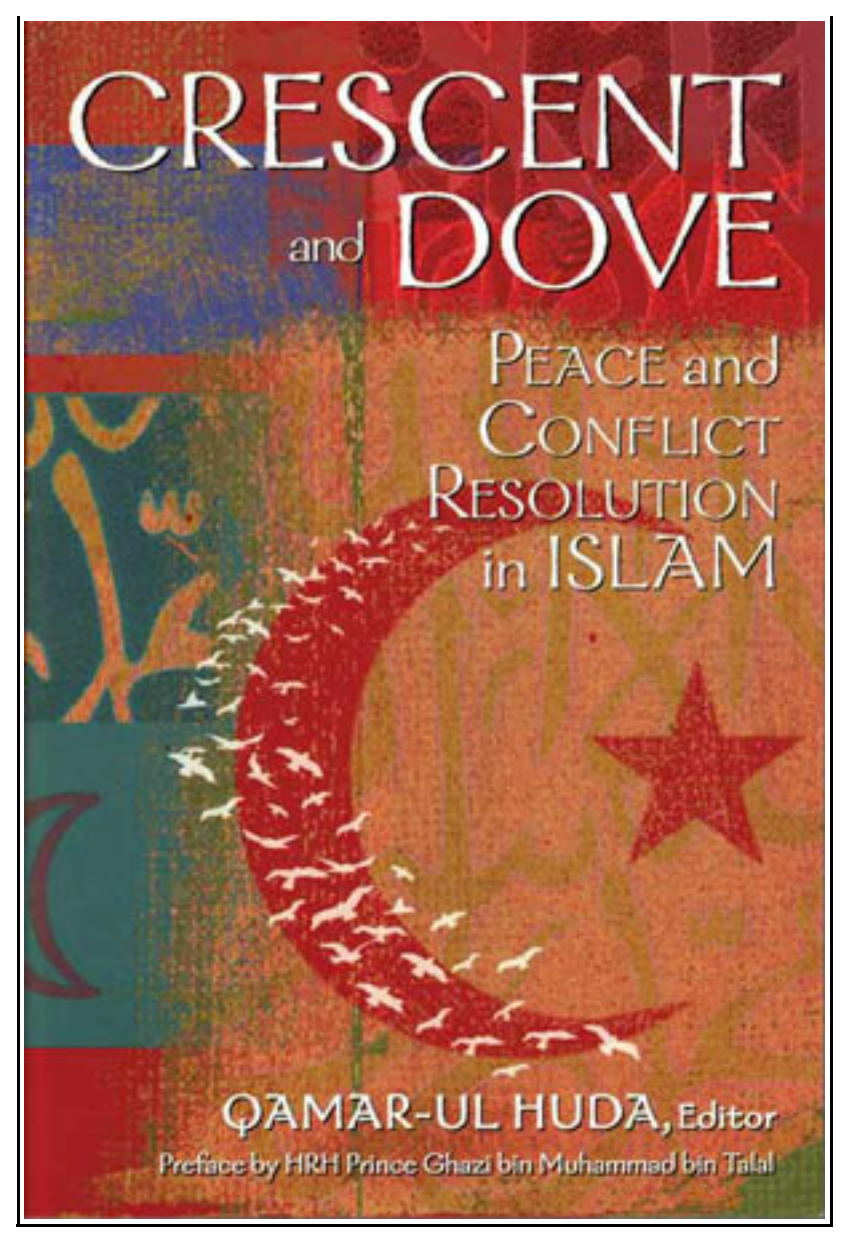

Tel: +15405682503

http://cisr.jmu.edu

TOP OF PAGE

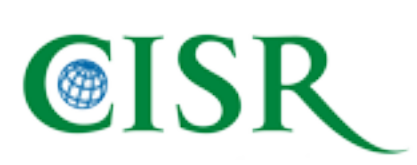

The Journal of ERW \& Mine Action is sponsored by:
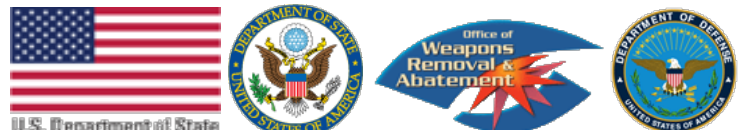

(C) 2011 All rights reserved. The Journal of ERW and Mine Action, Center for International Stabilization and Recovery at James Madison University. MSC 4902 Harrisonburg, VA / USA 22807 | Email: cisr@jmu.edu

If cited properly, short sections (a sentence or two) can be used without permission. Written Journal of ERW and Mine Action approval is required, however, before longer sections of content published in The Journal may be used by another source or publication. ISSN 2154-1485 